\title{
KINERJA BIDANG PENGAIRAN DALAM PENGELOLAAN JARINGAN IRIGASI PADA DINAS BINA MARGA DAN PENGAIRAN KABUPATEN SUBANG
}

\author{
Luki Natika \\ Dosen Program Studi Ilmu Administrasi Publik Fakultas Ilmu Administrasi Universitas Subang \\ Email :luki_natika@yahoo.com
}

\begin{abstract}
ABSTRAK
Penelitian dan penulisan ini membahas hal-hal yang berkaitan dengan kinerja Bidang Pengairan Dalam Pengelolaan Jaringan Irigasi Pada Dinas Bina Marga Dan Pengairan Kabupaten Subang dalam hubungannya dengan teori yaitu Produktivitas, Kualitas Layanan, Responsivitas, Responsibilitas dan Akuntabilitas. Dalam penelitian ini menggunakan pendekatan kualitatif melalui pengamatan dan observasi, wawancara, studi kepustakaan dan dokumentasi. Sumber data diperoleh dari informan melalui pengamatan dan wawancara secara langsung dan dokumen diperoleh dalam bentuk peraturan-peraturan dan pengolahan data.

Hasil penelitian menunjukan bahwa kinerja Bidang Pengairan Dalam Pengelolaan Jaringan Irigasi Pada Dinas Bina Marga Dan Pengairan Kabupaten Subang belum optimal. Masih harus diperhatikan upaya-upaya pengelolaan sumber daya air terutama pengelolaan jaringan irigasi yang dilakukan secara terpadu untuk meningkatkan koordinasi dan sinergitas dalam upaya konservasi, pendayagunaan, dan pengendalian daya rusak air serta memberikan pelayanan prima bagi masyarakat dalam memenuhi semua kebutuhan air secara tepat waktu, ruang, jumlah, dan mutu secara berkesinambungan.
\end{abstract}

Kata Kunci : Kinerja

\section{PENDAHULUAN}

Pelaksanaan kegiatan pembangunan nasional sesungguhnya merupakan salah satu upaya untuk mewujudkan cita-cita bangsa yakni terciptanya kesejahteraan masyarakat yang adil dan makmur. Pencapaian cita-cita tersebut dilaksanakan secara sistematis dan terpadu dalam bentuk operasional penyelenggaraan pemerintahan, selaras dengan fenomena dan dinamika yang terjadi di dalam kehidupan masyarakat. Penyelenggaraan pemerintahan dan pelaksanaan pembangunan tergantung dari pada penyempurnaan dan tanggung jawab dari aparatur Negara dan pegawainya yang berperan sebagai penentu kebijakan maupun sebagai pelaksana dalam menyelesaikan suatu pekerjaan. Untuk itu mereka dituntut untuk memiliki kemampuan berpikir dan terampil sesuai dengan beban dan bidang tugasnya.

Pemerintah Daerah Kabupaten Subang melalui Dinas Bina Marga dan Pengairan Kabupaten Subang melaksanakan salah satu tugas pokoknya yaitu penyelenggaraan urusan pemerintahan dan pelayanan umum di bidang Bina Marga dan Pengairan sesuai dengan ketentuan yang ditetapkan oleh Bupati melalui Peraturan Bupati No. 14 Tahun 2008 tentang Tugas Pokok dan Fungsi Dinas Bina Marga dan Pengairan Kabupaten Subang . Salah satu dari tugas pokok tersebut diantaranya adalah pengelolaan sumber daya air terutama pengelolaan jaringan irigasi yang dilakukan secara terpadu untuk meningkatkan koordinasi dan sinergitas dalam upaya konservasi, pendayagunaan, dan pengendalian daya rusak air serta memberikan pelayanan prima bagi masyarakat dalam memenuhi semua kebutuhan air secara tepat waktu, ruang, jumlah, dan mutu secara berkesinambungan. Daerah Irigasi yang ada di Kabupaten Subang pengelolaanya melalui Dinas Bina Marga dan Pengairan Kabupaten Subang yaitu sebanyak 289 Daerah Irigasi yang pengelolaannya di bawah $1.000 \mathrm{Ha}$. Pengelolaan jaringan irigasi di Kabupaten Subang diatur melalui Peraturan Daerah Kabupaten Subang Nomor 14 Tahun 2011 tentang Irigasi, mengingat irigasi merupakan salah satu faktor pendukung dalam pembangunan pertanian dan menunjang peran yang sangat penting dalam rangka menunjang ketahanan pangan. Untuk itu diperlukan penyediaan air bersih yang secara kualitas memenuhi standar yang berlaku dan secara kuantitas dan kontinuitas harus memenuhi kebutuhan masyarakat umum sehingga proses produksi tersebut dapat berjalan dengan baik. Air sebagai milik umum (common property) dianggap tidak terbatas adanya dan karenanya dapat diperoleh secara cuma-cuma atau gratis. Padahal, air sebagai sumberdaya alam, adalah terbatas 
jumlahnya karena memiliki siklus tata air yang relatif tetap. Ketersediaan air tidak merata penyebarannya dan tidak pernah bertambah. Kecenderungan menurunnya kualitas air akan meningkat seiring dengan meningkatnya perkembangan industri yang mengeluarkan limbah, pertumbuhan perumahan yang tumbuh secara pesat dan pertambahan penggunaan bahan-bahan organik sintetis.

Sesuai dengan Kepmen PU No :390/KPTS/M/2007 tentang penetapan status daerah irigasi yang pengelolaannya menjadi wewenang dan tanggung jawab pemerintah propinsi dan pemerintah kabupaten/kota. Untuk kewenangan pemerintah pusat pengelolaannya di atas $3.000 \mathrm{Ha}$, Pemerintah Propinsi pengelolaannya di atas $1.000-3.000 \mathrm{Ha}$ dan untuk kewenangan pemerintah Kabupaten/Kota dalam hal ini Kabupaten Subang pengelolaannya di bawah $1.000 \mathrm{Ha}$, pengelolaannya melalui Dinas Bina Marga dan Pengairan melalui Bidang Pengairan dengan jumlah 289 daerah irigasi dengan luas areal $28.650 \mathrm{Ha}$

Berdasarkan hasil penelitian penulis pada Dinas Bina Marga dan Pengairan Kabupaten Subang diketahui kinerja pengelolaan jaringan irigasi belum optimal hal ini dapat dilihat dari indikator sebagai berikut :

1. Terjadinya krisis air yang dipicu oleh sikap dan perilaku masyarakat, terlihat adanya penebangan hutan secara liar mengakibatkan lahan menjadi gundul mengurangi resapan air.

2. Terjadinya pencemaran air sebagai akibat adanya limbah industri, tidak semua perusahaan menggunakan Instalasi Pengelolaan Air Limbah (IPAL), contoh PT Sinkona Indonesia Lestari Desa Sarireja Kecamatan Jalancagak terdapat limbah yang mengalir ke saluran air yang mengakibatkan pencemaran.

3. Belum efektifnya pengelolaan jaringan irigasi akibat kondisi geografis yang mempengaruhi kualitas air sehingga sumber daya air yang ada belum benar-benar potensial atau belum sesuai dengan standar pengelolaan jaringan irigasi. Di daerah pegunungan propitasnya lebih besar dibandingkan dengan daerah aliran dataran karena tanahnya lekat atau tanah liat

\section{RUMUSAN MASALAH}

$\begin{array}{lccr}\text { Berdasarkan } & \text { kepada latar } & \text { belakang } \\ \text { permasalahan di } & \text { atas, penulis } & \text { dapat } \\ \text { mengidentifikasikan } & \text { masalahnya } & \text { adalah } \\ \text { Bagaimana kinerja } & \text { Bidang } & \text { Pengairan } & \text { Dalam } \\ \text { Pengelolaan Jaringan } & \text { Irigasi Pada Dinas } & \text { Bina } \\ \text { Marga Dan Pengairan Kabupaten Subang?, serta }\end{array}$

Unsur apa saja yang mempengaruhi kinerja Bidang Pengairan Dalam Pengelolaan Jaringan Irigasi Pada Dinas Bina Marga Dan Pengairan Kabupaten Subang?

\section{KAJIAN TEORITIS}

\section{Konsep Kinerja}

Kinerja merupakan suatu proses yang berkenaan dengan aktivitas sumber daya manusia dalam melakukan pekerjaan yang ditugaskan. Mengingat kinerja adalah aktivitas yang berkaitan dengan unsur yang terlibat dalam suatu proses untuk menghasilkan sesuatu maka penilaian diperlukan sebagai dasar untuk memproduksi atau pengembangan. Menurut Sedarmayanti (2004:46) kinerja atau performance adalah prestasi yang dihasilkan dari suatu proses atau cara bertindak dalam suatu fungsi atau lebih. Pendapat tersebut menunjukan bahwa kinerja menempatkan proses yang berkenaan dengan aktivitas sumber daya manusia dalam melaksanakan tugas dan fungsinya, untuk meningkatkan kemampuan dan keterampilan yang menghasilkan sesuatu dalam pencapaian tujuan organisasi. Sedangkan Rue \& Byar (dalam Pasolong, 2010:175) mengatakan bahwa kinerja adalah sebagai tingkat pencapaian hasil. Murphy dan Clevelend (dalam Pasolong, 2010:175) mengatakan bahwa kinerja adalah kualitas perilaku yang berorientasi pada tugas atau pekerjaan. Selanjutnya Robbins (Pasolong, 2010:176) menyatakan bahwa kinerja adalah hasil evaluasi terhadap pekerjaan yang dilakukan oleh pegawai dibandingkan kriteria yang telah ditetapkan sebelumnya.

Berdasarkan pendapat-pendapat tersebut dapat dilihat bahwa kinerja (performance) pegawai bisa diartikan sebagai hasil kerja yang dicapai oleh seseorang atau sekelompok orang dalam suatu organisasi baik secara kualitas maupun secara kuantitas dengan wewenang dan tanggung jawab dalam upaya mencapai tujuan organisasi. Mengacu pada pengertian di atas, bahwa unsur pembentuk kinerja organisasi adalah terdiri atas kinerja strategik, kinerja administratif, dan kinerja operasional, maka dapat didefinisikan bahwa kinerja organisasi adalah "hasil kerja yang secara akumulatif dicapai oleh organisasi berdasarkan sasaran yang ditetapkan untuk mencapai tujuan yang ditentukan sebelumnya".

Peneliti akan mengemukakan pengertian organisasi dari beberapa ahli. Adapun pengertian organisasi menurut para ahli diantaranya dikemukakan oleh Siagian (2006:6), menjelaskan organisasi adalah : 
Setiap bentuk persekutuan antara dua orang atau lebih yang bekerja bersama serta secara formal terikat dalam rangka pencapaian suatu tujuan yang telah ditentukan dalam ikatan yang terdapat seorang atau beberapa orang yang disebut atasan dan seorang atau sekelompok orang yang disebut bawahan.

Definisi di atas menunjukkan bahwa orgaisasi dapat ditinjau dari dua segi pandangan, yaitu sebagai organisasi sebagai wadah di mana kegiatan - kegiatan administrasi dijalankan dan organisasi sebagai rangkaian hierarki dan interaksi antara orang - orang dalam suatu ikatan formal. Menurut Dimock dalam Tangkilisan (2005:132), mendefinisikan organisasi sebagai berikut:

Organisasi adalah suatu cara yang sistematis untuk memadukan bagian-bagian yang saling tergantung menjadi suatu kesatuan yang utuh di mana kewenangan, koordinasi, dan pengawasan dilatih untuk mencapai tujuan yang telah ditentukan.

Menurut Dwight Waldo dalam Kencana Syafie (2004:96), menjelaskan Organisasi sebagai suatu struktur dan kewenangan-kewenangan dan kebiasaan dalam hubungan antar orang-orang pada suatu sistem administrasi.

Dari definisi tersebut di atas dapat diketahui bahwa organisasi adalah wadah atau tempat terselenggaranya administrasi, di dalamnya terjadi hubungan antar individu atau kelompok, baik dalam organisasi itu sendiri maupun keluar organisasi, terjadi kerja sama dan pembagian tugas dalam organisasi tersebut, berlangsungnya proses aktivitas berdasarkan kinerja masing-masing.

Kinerja organisasi merupakan indikator tingkatan prestasi yang dapat dicapai dan mencerminkan keberhasilan suatu organisasi, serta merupakan hasil yang dicapai dari perilaku anggota organisasi.

Menurut Atmosudirdjo (Pasolong, 2010:176) mengemukakan bahwa :

Kinerja organisasi adalah sebagai efektivitas organisasi secara menyeluruh untuk kebutuhan yang ditetapkan dari setiap kelompok yang berkenaan melalui usaha-usaha yang sistemik dan meningkatkan kemampuan organisasi secara terus menerus untuk mencapai kebutuhannya secara efektif

Selanjutnya Surjadi

mengemukakan juga bahwa "Kinerja organisasi adalah totalitas hasil kerja yang dicapai suatu organisasi tercapainya tujuan organisasi berarti bahwa, kinerja suatu organisasi itu dapat dilihat dari tingkatan sejauh mana organisasi dapat mencapai tujuan yang didasarkan pada tujuan yang sudah ditetapkan sebelumnya".

Menurut Sobandi (2006:176) kinerja organisasi merupakan sesuatu yang telah dicapai oleh organisasi dalam kurun waktu tertentu, baik yang terkait dengan input, output, outcome, benefit, maupun impact. Kinerja bisa juga dikatakan sebagai sebuah hasil (output) dari suatu proses tertentu yang dilakukan oleh seluruh komponen organisasi terhadap sumber-sumber tertentu yang digunakan (input). Selanjutnya, kinerja juga merupakan hasil dari serangkaian proses kegiatan yang dilakukan untuk mencapai tujuan tertentu organisasi. Bagi suatu organisasi, kinerja merupakan hasil dari kegiatan kerjasama diantara anggota atau komponen organisasi dalam rangka mewujudkan tujuan organisasi.

Pengukuran kinerja merupakan suatu kegiatan yang sangat penting karena dapat digunakan sebagai keberhasilan suatu organisasi dalam mencapai misinya. Menurut Dwiyanto (2006:45), mengukur kinerja organisasi publik, sangat berguna untuk menilai seberapa jauh pelayanan yang diberikan oleh organisasi itu memenuhi harapan dan memuaskan pengguna jasa.

Menurutnya, dengan melakukan penilaian terhadap kinerja maka upaya untuk memperbaiki kinerja bisa dilakukan secara terarah dan sistematis Informasi mengenai kinerja ini pula sangat penting guna menciptakan tekanan bagi pejabat penyelenggara pelayanan untuk melakukan perubahan-perubahan dalam organisasi. Dengan demikian, maka penilaian dengan mudah dapat dilakukan dan dorongan untuk memperbaiki kinerja bisa diciptakan.

Indikator yang digunakan untuk mengukur kinerja organisasi publik, menurut Dwiyanto (2006:50-51), yaitu sebagai berikut:

1. Produktivitas; Konsep produktivitas tidak hanya mengukur tingkat efisiensi, tetapi juga efektivitas pelayanan. Produktivitas pada umumnya dipahami secara umum sebagai rasio antara input dengan output. 
2. Kualitas Layanan; Isu mengenai kualitas layanan cenderung menjadi penting dalam menjelaskan kinerja organisasi publik. Hal ini disebabkan adanya pandangan negatif yang terbentuk mengenai organisasi publik muncul karena ketidakpuasan masyarakat terhadap kualitas layanan yang diterima. Dengan demikian kualitas layanan dapat dijadikan indikator kinerja organisasi publik.

3. Responsivitas; Responsivitas adalah kemampuan organsiasi untuk mengenali kebutuhan masyarakat, menyusun agenda dan prioritas pelayanan, dan mengembangkan programprogram pelayanan, dan mengembangkan programprogram pelayanan publik sesuai dengan kebutuhan dan aspirasi masyarakat. Secara singkat responsivitas di sini menunjuk pada keselarasan antara program dan kegiatan pelayanan dengan kebutuhan dan aspirasi masyarakat. Responsivitas dimasukkan sebagai salah satu indikator kinerja karena responsivitas secara langsung menggambarkan kemampuan organisasi publik dalam menjalankan misi dan tujuannya, terutama untuk memenuhi kebutuhan masyarakat.

4. Responsibilitas;

Responsibilitas menjelaskan apakah pelaksanaan kegiatan organisasi publik itu dilakukan sesuai dengan prinsip-prinsip administrasi yang benar atau sesuai dengan kebijakan organisasi, baik yang eksplisit maupun implisit. Oleh sebab itu itu, responsibilitas bisa saja pada suatu ketika berbenturan dengan reponsivitas.
5. Akuntabilitas; Akuntabilitas publik menunjuk pada seberapa besar kebijakan dan kegiatan organisasi publik tunduk pada para pejabat politik yang dipilih oleh rakyat. Dalam konteks ini, konsep akuntabilitas publik dapat digunakan untuk melihat seberapa besar kebijakan dan kegiatan organisasi publik tersebut konsisten dengan kehendak masyarakat banyak.

Selanjutnya Kumorotomo (2002:16-17) menggunakan beberapa kriteria untuk dijadikan pedoman dalam menilai kinerja organisasi publik antara lain sebagai berkut :

1. Efisiensi;

Efisiensi menyangkut pertimbangan tentang keberhasilam organsisasi publik mendapatkan laba, memanfaaatkan faktor-faktor produksi serta pertimbangan yang berasal dari rasionalitas ekonomis.

2. Efektivitas; Apakah tujuan dari didirikannya organisasi publik tersebut tercapai. Hal tersebut erat kaitannya dengan rasionalitas teknis, nilai, misi, tujuan organisasi, serta fungsi agen pembangunan.

3. Keadilan; Keadilan mempertanyakan distribusi dan alokasi layanan yang diselenggarakan oleh organsiasi publik.

4. Daya Tanggap; Organisasi publik merupakan bagian dari daya tanggap negara atau pemerintah akan kebutuhan vital masyarakat. Oleh sebab itu, kriteria organisasi tersebut secara keseluruhan harus dapat dipertanggungjawabkan secara transparan demi kriteria daya tanggap ini.

Dari uraian mengenai konsep-konsep kinerja tersebut di atas, maka peneliti beranggapan bahwa mengukur kinerja adalah mengukur pencapaian hasil (tujuan dari organisasi) dalam kurun waktu tertentu. 
Pengukuran kinerja organisasi publik tidak cukup hanya dilakukan dengan menggunakan indikator-indikator yang melekat pada organisasi publik tersebut, penilaian kinerja dari sisi pengguna jasa ini menjadi sangat penting karena organisasi publik seringkali memiliki kewenangan monopolis sehingga para perngguna jasa tidak memiliki alternatif sumber pelayanan. Berbeda dengan organisasi pelayanan yang diselenggarakan pasar, yang pengguna jasa memiliki pilihan sumber pelayanan, dalam pelayanan oleh birokrasi publik penggunaan pelayanan oleh publik sering tidak ada hubungannya sama sekali dengan kepuasannya terhadap pelayanan. Unsur-unsur penilaian kinerja adalah jelas merupakan dasar yang fundamental dalam kegiatan organisasi yang harus diperhatikan untuk terciptanya suatu rencana yang dapat dipedomani tujuan organisasi. Untuk mencapai tujuan organisasi tersebut perlu adanya kinerja yang tinggi dari organisasi itu sendiri.

Dari uraian konsep-konsep kinerja di atas, maka penulis beranggapan bahwa mengukur kinerja adalah mengukur pencapaian hasil dalam keadaan waktu tertentu.

\section{Konsep Irigasi}

Kartasapoetra (2011: 45) mengemukakan Irigasi adalah upaya pemberian air dalam bentuk lengas (kelembaban) tanah sebanyak keperluan untuk tumbuh dan berkembang bagi tanaman. Dengan kata lain irigasi adalah penambahan kekurangan kadar air tanah secara buatan yakni dengan memberikan air secara sistematis pada tanah yang diolah. Kebutuhan air irigasi untuk pertumbuhan tergantung pada banyaknya atau tingkat pemakaian dan efisien jaringan irigasi yang ada

Kartasapoetra (2011:30-31) juga mengemukakan jaringan irigasi merupakan prasarana irigasi yang terdiri atas bangunan dan saluran air beserta pelengkapnya. Sistem jaringan irigasi dapat dibedakan antara jaringan irigasi utama dan jaringan irigasi tersier. Jaringan irigasi utama meliputi bangunan-bangunan utama yang dilengkapi dengan saluran pembawa, saluran pembuang. dan bangunan pengukur. Jaringan irigasi tersier merupakan jaringan irigasi di petak tersier, beserta bangunan pelengkap lainnya yang terdapat di petak tersier

$$
\text { Menurut Najiyati (2007:35-36) }
$$

berdasarkan letak dan fungsinya saluran irigasi teknis dibedakan menjadi

a. Saluran Primer (Saluran Induk) yaitu saluran yang lansung berhubungan dengan saluran bendungan yang fungsinya untuk menyalurkan air dari waduk ke saluran lebih kecil.

b. Saluran Sekunder yaitu cabang dari saluran primer yang membagi saluran induk kedalam saluran yang lebih kecil (tersier).

c. Saluran Tersier yaitu cabang dari saluran sekunder yang langsung berhubungan dengan lahan atau menyalurkan air ke saluran saluran kwarter.

d. Saluran kwarter yaitu cabang dari saluran tersier dan berhubungan langsung dengan lahan pertanian.

Irigasi merupakan bangunan air yang berupa saluran dan berfungsi menyalurkan air dari Bendung ke petak secara periodik, guna mencukupi kebutuhan air bagi tanaman di petak sawah.

Peranan irigasi dalam memenuhi kebutuhan air untuk tanaman padi dapat di ketahui melalui suatu kajian yang cermat pada masalah masalah tentang irigasi, dengan memperhatikan beberapa faktor yang mempengaruhi pengelolaan kegiatan penyediaan dan pemberian air secara efektif dan efisien. Menurut Hansen (2006:4) Peranan irigasi bagi suatu lahan dapat dijabarkan sebagai berikut :

a. Menambah air ke dalam tanah untuk menyediakan cairan yang diperlukan untuk pertumbuhan tanaman.

b. Menyediakan jaminan panen pada musim kemarau yang pendek.

c. Mendinginkan tanah dan atmosfer, sehingga menimbulkan lingkungan yang baik untuk pertumbuhan tanaman.

d. Mengurangi bahaya pembekuan.

e. Mencuci atau mengurangi garam dalam tanah.

f. Mengurangi bahaya erosi.

g. Melunakan pembajakan dan pengumpalan tanah.

h. Memperlambat pembentukan tunas dengan perbandingan karena penguapan.

Berkaitan dengan perkembangan teknologi budidaya dan produksi pangan, peranan irigasi menurut Hansen (2006:4).berkembang menjadi :

a. Penyedia air untuk tanaman dan dapat digunakan untuk mengatur kelembaban tanah.

b. Membantu menyuburkan tanah melalui bahan - bahan pangan kandungan yang di bawa oleh air.

c. Memungkinkan penggunaan obat - obatan dalam dosis.

d. Menekan pertumbuhan gulma.

e. Menekan perkembangan hama tertentu.

f. Memudahkan pengeolahan tanah 
Adapun cara mengetahui banyaknya dan lamanya aliran air irigasi menurut Najiyati (2007:35-36) yaitu saluran irigasi yang baik akan dapat memenuhi kebutuhan air pada lahan persawahan. Kualitas saluran juga berkaitan dengan material binaan pada saluran. Material yang banyak di gunakan untuk lapisan pada saluran berupa beton, pasangan batu, pasangan bata, campuran tanah dan bentonite lempung alam dengan permeabilitas rendah dengan berbagai karet, plastik susunan aspal. Air irigasi yang masuk ke lahan pertanian dapat diketahui dengan cara menghitung kapasitas saluran irigasi atau debit air irigasi, dengan maksud agar pembagian air dalam suatu jaringan irigasi dapat dilaksanakan secara adil dan merata sehingga air yang dibutuhkan dapat mencukupi.

\section{METODE PENELITIAN}

Dalam penelitian ini, penulis menggunakan pendekatan kualitatif, yang berbasis pada informasi/kenyataan yang terjadi di lapangan. Adapun prosedur-prosedur pada pendekatan kualitatif yaitu : pengambilan sampel secara sengaja, pengumpulan data terbuka, analisis teks atau gambar, penyajian informasi dalam bentuk gambar dan tabel, serta interpretasi pribadi atas temuan-temuan. Langkah-langkah untuk pengumpulan data meliputi usaha membatasi penelitian, mengumpulkan informasi melalui observasi dan wawancara, baik yang terstruktur maupun tidak, dokumentasi, materi-materi visual, serta usaha merancang protokol untuk merekam / mencatat informasi

Jenis penelitian yang digunakan dalam penelitian ini adalah deskriptif kualitatif, karena penelitian ini bertujuan untuk memperoleh gambaran variabel yang diteliti. Dalam hal penelitian ini penulis mengungkapkan penelitian kualitatif dengan penelitian yang dilakukan dalam setting tertentu yang ada dalam kehidupan sebenarnya dengan maksud menginvestigasi dan memahami fenomena apa yang terjadi yaitu kinerja Bidang Pengairan Dalam Pengelolaan Jaringan Irigasi Pada Dinas Bina Marga Dan Pengairan Kabupaten Subang. Denzin dan Lincoln (Moleong, 2005:4) menyatakan bahwa metodologi kualitatif penelitian yang menggunakan latar belakang alamiah, dengan maksud menafsirkan fenomena yang terjadi dan dilakukan dengan jalan melibatkan berbagai metode yang ada.

\section{PEMBAHASAN}

Penilaian suatu kinerja dalam organisasi dapat dijadikan sebagai ukuran keberhasilan suatu organisasi dalam mencapai misi yang ditetapkan.
Sehingga penilaian kinerja sangat dianggap penting. Suatu pelayanan yang optimal adalah jika didalamnya terdapat dimensi-dimensi yang digunakan untuk tolak ukur keberhasilan. Dalam bab ini akan dibahas tentang hasil dan pembahasan dalam penelitian tentang kinerja Dinas Bina Marga Dan Pengairan Kabupaten Subang. Untuk mengukur kinerja Bidang Pengairan Dalam Pengelolaan Jaringan Irigasi Pada Dinas Bina Marga Dan Pengairan Kabupaten Subang digunakan dimensi-dimensi Produktivitas, Kualitas Pelayanan, Responsivitas, Responsibilitas dan Akuntabilitas. Selain itu juga akan dibahas kendala yang dihadapi oleh dalam pelaksanaan Pengelolaan jaringan irigasi.

\section{Dimensi Produktivitas}

Dwiyanto (2006:50-51) mengemukakan bahwa konsep produktivitas tidak hanya mengukur tingkat efisiensi, tetapi juga efektivitas pelayanan. Produktivitas pada umumnya dipahami secara umum sebagai rasio antara input dengan output. Produktivitas juga merupakan bentuk kemampuan organisasi untuk mengenali kebutuhan masyarakat dalam pelayanan publik.. Dalam penelitian ini produktivitas di Dinas Bina Marga Dan Pengairan Kabupaten Subang meliputi pelayanan yang dikeluarkan oleh Dinas Bina Marga Dan Pengairan Kabupaten Subang.

Dalam menjalankan tugasnya, Dinas Bina Marga Dan Pengairan Kabupaten Subang mempunyai tugas pokok melaksanakan penyelenggaraan pemerintahan, pembangunan dan pembinaan kehidupan kemasyarakatan di wilayah kerjanya.

Segi Produktivitas di Dinas Bina Marga Dan Pengairan Kabupaten Subang mempunyai tujuan untuk melayani masyarakat dengan baik. Pelayanan yang diberikan oleh Dinas Bina Marga Dan Pengairan Kabupaten Subang juga cepat, sehingga menjadikan Dinas Bina Marga Dan Pengairan Kabupaten Subang lebih unggul dengan adanya pelayanan yang berkualitas.

Bahwa Dinas Bina Marga Dan Pengairan Kabupaten Subang dari segi produktivitas melaksanakan program pengelolaan jaringan irigasi adalah kegiatan yang dilakukan oleh pemerintah, melalui pembangunan diantaranya infrastruktur irigasi. Infrastruktur irigasi sangat menentukan ketersediaan air yang berdampak langsung terhadap kualitas dan kuantitas tanaman. Produktivitas, harus diimbangi dengan peningkatan pelayanan yang pro rakyat. memfokuskan pada pengelolaan jaringan irigasi menjadi hak dan tanggung jawab petani pemakai air (P3A). Mengenai penyelesaian Pengelolaan jaringan 
irigasi sesuai tuntutan masyarakat yang masuk ke Dinas Bina Marga Dan Pengairan Kabupaten Subang,

Penulis menjelaskan bahwa produktivitas Dinas Bina Marga Dan Pengairan Kabupaten Subang dalam menjalankan pengelolaan jaringan irigasi cukup baik meskipun dalam kenyataan di lapangan pendataannya masih terdapat kekeliruan. Produktivitas Dinas Bina Marga Dan Pengairan Kabupaten Subang cukup baik jika dilihat dari pelayanan-pelayanan yang diberikan.

\section{Dimensi Kualitas Pelayanan}

Dwiyanto (2006:50-51) mengemukakan bahwa isu mengenai kualitas layanan cenderung menjadi penting dalam menjelaskan kinerja organisasi publik. Hal ini disebabkan adanya pandangan negatif yang terbentuk mengenai organisasi publik muncul karena ketidakpuasan masyarakat terhadap kualitas layanan yang diterima. Dengan demikian kualitas layanan dapat dijadikan indikator kinerja organisasi publik.

Seperti yang telah dijelaskan di muka, bahwa kinerja oganisasi publik juga dapat dilihat dari kualitas pelayanan yang diberikan organisasi publik tersebut kepada masyarakat. Kualitas pelayanan Dinas Bina Marga Dan Pengairan Kabupaten Subang adalah bagaimana dalam memberikan pelayanan kepada masyarakat dan menyangkut pertanggungjawaban Dinas Bina Marga Dan Pengairan Kabupaten Subang dalam Pengelolaan jaringan irigasi.

Selanjutnya, salah satu bentuk kualitas pelayanan adalah mengenai sosialisasi Pengelolaan jaringan irigasi di Dinas Bina Marga Dan Pengairan Kabupaten Subang menyangkut pada pelayanan kepada masyarakat. Karena sebagai penyedia pelayanan, harus selalu memperhatikan sosialisasi untuk suatu kegiatan pelayanan kepada masyarakat mengenai pengelolaan jaringan irigasi. Karena sosialisasi yang baik, akan mempengaruhi persepsi masyarakat terhadap kualitas pelayanan..

Penulis dapat dicermati bahwa pernyataan tersebut secara tidak langsung mengindikasikan bahwa sosialisasi telah dilakukan oleh kepada masyarakat, tetapi sebagian masyarakat tidak mengetahui tentang pengelolaan jaringan irigasi baik dari prosedur maupun ketentuannya.

Dari segi kualitas layanan, sosialisasi pengelolaan jaringan irigasi oleh petugas Dinas Bina Marga Dan Pengairan Kabupaten Subang sudah cukup baik pelaksanaannya. Dinas Bina Marga Dan Pengairan Kabupaten Subang sebagai organisasi penyedia jasa pelayanan dituntut untuk memberikan pelayanan yang maksimal dan berkualitas. Untuk itu, jumlah pegawai sangat mempengaruhi dalam menciptakan pelayanan yang berkualitas. Karena pegawai adalah pelaksana kegiatan dalam memberikan pelayanan kepada masyarakat peserta Pengelolaan jaringan irigasi. Dengan terpenuhinya jumlah pegawai, diharapkan semua pekerjaan dapat diselesaikan..

\section{Dimensi Responsivitas}

Dwiyanto (2006:50-51) mengemukakan bahwa responsivitas adalah kemampuan organsiasi untuk mengenali kebutuhan masyarakat, menyusun agenda dan prioritas pelayanan, dan mengembangkan program-program pelayanan, dan mengembangkan program-program pelayanan publik sesuai dengan kebutuhan dan aspirasi masyarakat. Secara singkat responsivitas di sini menunjuk pada keselarasan antara program dan kegiatan pelayanan dengan kebutuhan dan aspirasi masyarakat. Responsivitas dimasukkan sebagai salah satu indikator kinerja karena responsivitas secara langsung menggambarkan kemampuan organisasi publik dalam menjalankan misi dan tujuannya, terutama untuk memenuhi kebutuhan masyarakat

Dinas Bina Marga Dan Pengairan Kabupaten Subang adalah salah satu organisasi pelayanan publik yang selalu berusaha memberikan pelayanan terbaik berupa pelayanan prima agar dapat memenuhi kebutuhan dan harapan masyarakat. Untuk itu dituntut Dinas Bina Marga Dan Pengairan Kabupaten Subang harus selalu tanggap terhadap kebutuhan masyarakat serta terhadap keluhan-keluhan yang disampaikan masyarakat.

Konsep responsivitas mengarah pada pertanggungjawaban organisasi publik dalam memberikan pelayanan kepada masyarakat. Respon yang diharapakan dari pengguna pelayanan kepada Dinas Bina Marga Dan Pengairan Kabupaten Subang adalah daya tanggap Dinas Bina Marga Dan Pengairan Kabupaten Subang dalam melayani dan memenuhi kebutuhan masyarakat dengan cepat dan tanpa prosedur yang berbelit-belit serta tepat waktu.

Sikap responsif dari Dinas Bina Marga Dan Pengairan Kabupaten Subang dapat dilihat dari bagaimana Dinas Bina Marga Dan Pengairan Kabupaten Subang dalam memberikan dan menyediakan sarana pelayanan. Kebutuhan pelayanan disini mencakup segala sarana yang dibutuhkan pegawai Dinas Bina Marga Dan Pengairan Kabupaten Subang untuk melayani pelanggan. Untuk itu Dinas Bina Marga Dan Pengairan Kabupaten Subang dituntut untuk mempunyai fasilitas yang memadai yang akan menciptakan pelayanan yang berkualitas. 
Penulis menganalisis bahwa dari segi responsivitas, pada bagian ini pengelolaan jaringan irigasi harus dilaksanakan sebaik mungkin karena melupakan pelayanan publik yang diperuntukkan bagi masyarakat mengalami berbagai masalah pengairan. Dapat diketahui bahwa Dinas sudah melakukan sosialiasi pedoman teknis engelolaan jaringan irigasi, sesuai tugas dan fungsi Pengelolaan jaringan irigasi itu sendiri, meskipun kenyataan dilapangan masyarakat masih belum banyak mengerti dan mengetahui apa itu pengelolaan jaringan irigasi .

\section{Dimensi Responsibilitas}

Dwiyanto (2006:50-51) mengemukakan bahwa responsibilitas menjelaskan apakah pelaksanaan kegiatan organisasi publik itu dilakukan sesuai dengan prinsip-prinsip administrasi yang benar atau sesuai dengan pembinaan Pengelolaan jaringan irigasi baik yang eksplisit maupun implisit

Jadi seperti yang telah dibahas di muka bahwa responsibilitas dari Dinas Bina Marga Dan Pengairan Kabupaten Subang adalah kemampuan Dinas Bina Marga Dan Pengairan Kabupaten Subang dalam melaksanakan tugas dan tanggung jawabnya sesuai dengan standart profesional dan kompetensi aparatur pemerintah dengan mengarahkan Sumber Daya yang dimiliki untuk mencapai tujuan yang ditetapkan.

Para pegawai Dinas Bina Marga Dan Pengairan Kabupaten Subang harus mempunyai kemampuan yang diperlukan untuk memberikan pengarahan kepada masyarakat di Kabupaten Subang dalam rangka pelaksanaan pengelolaan jaringan irigasi.

Sumber daya manusia atau kemampuan pegawai merupakan faktor yang sangat penting dalam suatu organisasi karena mereka merupakan faktor penggerak roda organisasi. Untuk itu, maka diperlukan kemampuan yang memadai terutama bagi pelaksana suatu program sehingga dalam memberikan pelayanan tidak terjadi penyimpangan. Dengan adanya pemahaman terhadap kebijakan sering terjadi kurang adanya transmisi informasi.

Penulis menganalisis banyak yang menjawab harapan yang diinginkan oleh masyarakat berkaitan dengan pengelolaan jaringan irigasi ini adalah mereka menginginkan adanya perhatian lebih dari pemerintah agar lebih mensosialisasikan pengelolaan jaringan irigasi kepada masyarakat. Dapat diketahui bahwa dari segi Responsivitas, sosialisasi pengelolaan jaringan irigasi memerlukan sumber daya yang mampu memahami terutama peraturan-peraturan yang berlaku berkaitan dengan pengelolaan jaringan irigasi.

\section{Dimensi Akuntabilitas}

Dwiyanto (2006:50-51) mengemukakan bahwa akuntabilitas publik menunjuk pada seberapa besar pengelolaan jaringan irigasi dan kegiatan organisasi publik tunduk pada para pejabat politik yang dipilih oleh rakyat. Dalam konteks ini, konsep akuntabilitas publik dapat digunakan untuk melihat seberapa besar pembinaan program pengelolaan jaringan irigasi dan kegiatan organisasi publik tersebut konsisten dengan kehendak masyarakat banyak.

Akuntabilitas dalam penyelenggaraan pelayanan publik adalah suatu ukuran yang menunjukkan seberapa besar kesesuaian penyelenggaraan palayanan dengan petunjuk pelaksana yang menjadi dasar atau pedoman penyelenggaraan pelayanan kepada pihak yang memiliki kewenangan untuk meminta pertanggungjawaban tersebut.

Akuntabilitas Dinas Bina Marga Dan Pengairan Kabupaten Subang dapat diartikan sebagai bentuk pertanggungjawaban atas penyelenggaraan pelayanan kepada pihak yang memiliki hak dan wewenang untuk meminta pertanggungjawaban tersebut. Pertanggungjawaban Dinas Bina Marga Dan Pengairan Kabupaten Subang adalah kepada Bupati Subang.

Penulis menganalisis bahwa akuntabilitas Pengelolaan jaringan irigasi di sudah berjalan baik, namun belum maksimal, Dari hasil observasi penulis diketahui bahwa sebagian menyatakan bahwa mereka memberikan informasi yang dapat dipertanggungjawabkan melalui pedoman teknis sebagian informan menyatakan bahwa mereka memberikan informasi sesuai dengan pengetahuan yang mereka ketahui. Hal ini dikarenakan tingkat pengetahuan informan yang berbeda-beda dan sumber daya yang mereka miliki juga bervariasi.

Adapun kendala yang dihadapi oleh dalam pelaksanaan Pengelolaan jaringan irigasi, yaitu :

1. Produktivitas, belum diimbangi oleh peningkatan pelayanan yang memfokuskan pada pengelolaan jaringan irigasi

2. Kualitas Layanan, belum adanya kejelasan sosialisasi dari aparat kepada masyarakat mengenai pengelolaan jaringan irigasi, sosialisasi dilakukan cenderung untuk pihak tertentu, sementara masyarakat lainnya tidak mengetahui sepenuhnya

3. Responsivitas, pemahaman terhadap pengelolaan jaringan irigasi sering terjadi sehingga mempunyai pengaruh besar dalam 
pembentukan opini dan kepercayaan orang atau masyarakat terhadap keberadaan pengelolaan jaringan irigasi itu sendiri.

4. Responsibilitas, pemahaman aparat terhadap perkembangan pengelolaan jaringan irigasi masih rendah sehingga pada saat melakukan sosialisasi kepada masyarakat tidak begitu dipahami dan di mengerti

\section{KESIMPULAN}

Berdasarkan hasil penelitian dan pembahasan yang telah dilakukan pada bab sebelumnya mengenai kinerja Bidang Pengairan Dalam Pengelolaan Jaringan Irigasi Pada Dinas Bina Marga Dan Pengairan Kabupaten Subang, maka penulis mengambil kesimpulan sebagai berikut :

1. Dimensi Produktivitas, kinerja Bidang Pengairan Dalam Pengelolaan Jaringan Irigasi Pada Dinas Bina Marga Dan Pengairan Kabupaten Subang dalam menjalankan Pengelolaan jaringan irigasi cukup baik meskipun dalam kenyataan di lapangan pendataannya masih terdapat kekeliruan

2. Dimensi Kualitas Pelayanan, sosialisasi pengelolaan jaringan irigasi oleh cukup baik pelaksanaannya..

3. Dimensi Responsivitas, dapat dikatakan belum maksimal dan masih perlu ditingkatkan. Pengelolaan jaringan irigasi harus dilaksanakan sebaik mungkin karena melupakan pelayanan publik yang diperuntukkan bagi masyarakat yang mengalami masalah dengan pengairan.

4. Dimensi Responsibilitas, Bidang Pengairan mencoba mewujudkan harapan yang diinginkan oleh masyarakat berkaitan dengan Pengelolaan jaringan irigasi ini yaitu menginginkan adanya perhatian lebih dari pemerintah dalam mensosialisasikan pengelolaan jaringan irigasi ini.

5. Dimensi Akuntabilitas, Bidang Pengairan Dalam Pengelolaan Jaringan Irigasi Pada Dinas Bina Marga Dan Pengairan Kabupaten Subang belum maksimal, hasil wawancara dengan informan sebagian menyatakan bahwa mereka memberikan informasi yang dapat dipertanggungjawabkan tetapi sebaliknya ada sebagian informan menyatakan bahwa mereka memberikan informasi sesuai dengan pengetahuan yang mereka ketahui. Hal ini dikarenakan tingkat pengetahuan informan yang berbeda-beda dan sumber daya yang mereka miliki juga bervariasi..

\section{SARAN}

Berdasarkan dari pembahasan dan kesimpulan-kesimpulan yang ada, maka untuk memperbaiki kelemahan-kelemahan yang ditemukan dalam proses kinerja Bidang Pengairan Dalam Pengelolaan Jaringan Irigasi Pada Dinas Bina Marga Dan Pengairan Kabupaten Subang, dengan ini penulis memberikan saran sebagai berikut :

1. Pada Dimensi Produktivitas, adanya mekanisme yang lebih fleksibel dalam kepenggurusan apabila ada kesalahan teknis dalam proses kegiatan

2. Pada Dimensi Responsivitas, Bidang Pengairan supaya lebih meningkatkan upayaupaya agar masyarakat puas dengan pelayanan yang diberikan terutama selalu siap dalam menanggapi keluhan masyarakat.

3. Pada Dimensi Akuntabilitas Bidang Pengairan agar prosedur dalam memberikan pelayanan kepada masyarakat mengacu pada Pedoman Teknis. Sehingga pelayanan yang diberikan tetap berkualitas agar lebih fokus pada masyarakat terutama kalangan yang benarbenar memerlukan bantuan.

\section{DAFTAR PUSTAKA}

Dwiyanto, Agus, 2006, Penilaian Kinerja Organisasi Pelayanan Publik, Yogyakarta, Fisipol UGM

Handoko, T. H. 2001, Manajemen Personalia dan Sumber Daya Manusia. BPFE, Yogjakarta.

Kumurotomo, Wahyudi. 2002, Etika Administrasi Negara, Jakarta : Rajawali Pers

Mangkunegara, Anwar Prabu, 2000, Perencanaan dan Pengembangan Sumber Daya Manusia ${ }_{2}$ Jakarta, : Refika Aditama

Moeheriono, 2010, Pengukuran Kinerja Berbasis Kompetensi, Ghalia Indonesia, Bogot

Moenir, 2003, Pendekatan Manusia dan Organisasi Terhadap Pembinaan Kepegawaian, Gunung Agung, Jakarta,

Moleong, Lexy, J, MA, 2005, Metode Penelitian Kualitatif, Bandung, PT Remaja Rosdakarya

Nurlita Witarsa, 2008, Dasar-Dasar Produksi, Karunika, Jakarta,

Pasolong, Harbani, 2010, Teori Administrasi Publik, Alfabeta, Bandung

Prawirosentono, Sujadi. 2009. Kebijakan Kinerja Karyawan. Penerbit BPFE. Jogjakarta.

Sedarmayanti, 2004, Tata Kerja dan Produktivitas Kerja, CV Mandar Maju, Bandung 
Sobandi, Baban. 2006. Desentralisasi dan Tuntutan Penataan Kelembagaan Daerah. Bandung: Humaniora.

Sugiyono, Drs, 2007, Metode Penelitian Administrasi, Bandung: Alfabeta.

Surachmad, Wirjo, 2003, Wawasan Kerja Aparatur Negara, Pustaka Jaya, Jakarta

Surjadi, FX, 2009. Organization and Methods, PT.Midas Surya Grafindo, Jakarta.

Susanto, Astrid S, 2004, Komunikasi Dalam Teori dan Praktek, Bina Aksara, Jakarta

Wibowo, 2010 Manajemen Kinerja, Rajawali Press, Jakarta 